\title{
Land-use influence on the soil hydrology: An approach in upper Grande River basin, Southeast Brazil
}

\section{Influência do uso da terra na hidrologia do solo: Uma abordagem na bacia do Alto Rio Grande, sudeste do Brasil}

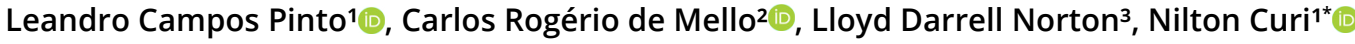

\author{
'Universidade Federal de Lavras/UFLA, Departamento de Ciência do Solo/DCS, Lavras, MG, Brasil \\ ${ }^{2}$ Universidade Federal de Lavras/UFLA, Departamento de Recursos Hídricos e Saneamento/DRS, Lavras, MG, Brasil \\ ${ }^{3}$ Purdue University/USDA-ARS, National Soil Erosion Research Laboratory, West Lafayette, Indiana, USA \\ ${ }^{*}$ Corresponding author: ntcuri@gmail.com \\ Received in July 7, 2019 and approved in September 27, 2019
}

\begin{abstract}
Brazil is a large country that depends on the hydroelectricity generation hydropower dams. The Upper Grande River Basin (UGRB) is one of the most important Brazilian hydrological regions in terms of water availability and electric energy production. Therefore, studies of water availability are indispensable for a better and more successful decision making in water resources management in the region. This study objective to approach the land-use influence on the soil hydrology in the Upper Grande River Basin, a strategic headwater basin of southeastern Brazil. This study uses hydrological indicators (baseflow/runoff (BF/R) and overland flow/runoff (OF/R)) extracted from eight watersheds, varying the size and localization in the region, to support the results found. Soil saturated hydraulic conductivity (Ko) was determined in situ using a constant flow permeameter, totaling 224 sampled points. Five machine learning algorithms were compared in their performance to predict Ko (Random Forest, Support Vector Machine, Gradient Boosting, Linear Regression, Regularization) using terrain attributes as covariates. The tested methods for predicting Ko resulted in a relatively low coefficient of determination ( $\mathrm{R}^{2}$ ) due to the high spatial variability of this soil hydrologic attribute. The hydrological indicator BF/R was sensitive to land-use changes in the watersheds. The greatest Ko values were associated with native forest and the least values area associated with pasture and rupestrian field.
\end{abstract}

Index terms: Land-use impacts; hydrological indicators; hydropedology.

\section{RESUMO}

A Bacia do Alto Grande (ARG) é responsável pela drenagem de vários rios no sudeste do Brasil, sendo uma região hidrológica de grande importância para o Sistema Elétrico Brasileiro. Portanto, estudos sobre a disponibilidade de água nesta região são indispensáveis para uma melhor tomada de decisão na gestão dos recursos hídricos. O objetivo deste estudo é abordar a influência do uso da terra nas propriedades hidrológicas do solo na ARG, uma bacia de cabeceira estratégica do sudeste do Brasil. Para apoiar os resultados encontrados, este estudo utiliza indicadores hidrológicos (Fluxo de base/escoamento superficial (FB/ES) e Fluxo superficial/escoamento superficial (FS/ ES)) extraídos de oito bacias hidrográficas. A condutividade hidráulica (Ko) foi determinada in situ usando um permeâmetro de fluxo constante, totalizando 224 pontos amostrados. Cinco algoritmos de aprendizado de máquina foram comparados em seu desempenho para prever a Ko (Random Forest, Support Vector Machine, Gradient Boosting, Linear Regression, Regularization) usando atributos de terreno como covariáveis. A validação adicional das relações de uso da terra e propriedades hidrológicas na ARG foi realizada com base em indicadores desenvolvidos com base nas séries pluviométricas e fluviométricas de longo prazo, de oito bacias hidrográficas dentro da ARG. Os métodos testados para prever a Ko resultaram em um $\mathrm{R}^{2}$ relativamente baixo devido à alta variabilidade espacial deste atributo hidrológico do solo. O indicador hidrológico FB/ES foi sensível às mudanças no uso da terra nas bacias hidrográficas. Os maiores valores de Ko estão associados à floresta nativa e os menores valores às áreas de pastagem e campo rupestre.

Termos para indexação: Impactos do uso do solo; indicadores hidrológicos; hidropedologia.

\section{INTRODUCTION}

The Upper Grande River Basin (UGRB) is responsible for the drainage of several rivers in Southeastern Brazil. It is a hydrologic region of great importance for the Brazilian Electric Energy System, feeding several reservoirs, where Furnas hydropower plant highlights. In addition, the streamflow from this region is the main source for irrigation and water supply for more than 66 cities in southern Minas Gerais State (Mello et al., 2019; Viola et al., 2015). 
Environmental impacts from misuse of the soils affect the soil hydrological function, harming the groundwater recharge and thus, affecting the natural flow regulation of the headwater regions (Costa et al., 2019; Germer et al., 2010; Oliveira et al., 2019; Owuor et al., 2018; Pinto; Mello; Ávila, 2013; Pinto et al., 2015; 2017; Price; Jackson; Parker, 2010; Salemi et al., 2013; Viola et al., 2014). Pinto et al. (2015) evaluated the role of the Inceptisols of the Mantiqueira Range region, in UGRB, on the hydrology of catchments under pasture and native forest. They found much higher saturated soil hydraulic conductivity in the forested watershed with greater base flow amount than in watersheds with predominance of pasture. On small scale catchment, Pinto et al. (2017) observed an intrinsic relationship between soil drainable porosity and land-use. They tested several methods for soil drainable porosity prediction and observed that when land-use was considered, the precision of the model significantly increased. Therefore, studies of water availability in this region are indispensable for a better and more successful decision making on soil-water conservation and management. In this direction, one of the most important processes to be understood in a watershed is the saturated soil hydraulic conductivity (Ko) behavior due to its intrinsic relationship with infiltration and thus with groundwater recharge.

Ko affects water flows and other hydrological and biogeochemical processes, including questions about how human-induced changes may affect the ecological balance. However, characterization of Ko covering extensive areas is expensive, long time consuming and complex, especially due to its high spatial variability, as reported in several studies (Bevington et al., 2016; Gwenzi et al., 2011; Jačka et al., 2016, 2018; Kurnianto et al., 2019; Moustafa, 2000; Papanicolaou et al., 2015; Rienzner; Gandolfi, 2014; Ronayne; Houghton; Stednick, 2012; Wang et al., 2018a; Zimmermann; Elsenbeer, 2008). This high spatial variability of Ko occurs due to different extrinsic and intrinsic factors, including geomorphic surface, weather, land-use and management, soil structure, soil granulometric distribution and bulk density (Sobieraj et al., 2002; Pachepsky et al., 2008; Zimmermann et al., 2013). Such variability may negatively affect the Ko prediction models (Marín-Castro et al., 2016). However, the spatial prediction of Ko should be tested, since models with good accuracy may generate great results for several applications.

In recent years, there has been a growing development of new techniques for soil hydrologic attributes mapping based on digital soil mapping (DSM) (Hengl et al., 2015; Camera et al., 2017; Menezes et al., 2018; Pahlavan-Rad; Akbarimoghaddam, 2018) in face of the computational techniques, leading to more accurate procedures (Papanicolaou et al., 2015).

New models have been developed and used for digital soil mapping aiming to extract the better physical information from soils. In this sense, a number of machine learning algorithms have been applied to DSM, such as Random Forest (RF) (Breiman, 2001), Support Vector Machine (SVM) (Vapnik, 1982), Gradient Boosting (GB) (Friedman, 2001), Linear Regression (LG) (Hastie; Tibshirani; Friedman, 2009), and Regularization (Reg) (Hastie; Tibshirani; Friedman, 2009). Although these models have been widely applied to soil attributes prediction, its applicability to Ko was not yet been further investigated under tropical soils in headwater basins.

It is noteworthy that there are few studies detailing the dynamics of soil water under the influence of the Upper Grande River Basin land-use (tropical condition). Although previous studies have shown a strong relationship of land-use with soil hydrology (Menezes et al., 2016; 2018; Pinto et al., 2015), such studies were designed on small scales. In addition, studies of these relationships on large scales are necessary for a better comprehension of the practical applicability on water resources management. Therefore, the overall hypothesis for this research is that land-use has a strong influence on soil hydrologic attributes in the tropical watersheds, even in a large-scale analysis.

In this sense, this study objective to approach the land-use influence on the soil hydrology in the Upper Grande River Basin, supported by some hydrological indicators (baseflow/runoff and overland flow/runoff) extracted from eight watersheds.

\section{MATERIAL AND METHODS}

\section{Site Description}

This study was developed in the upstream side of the UGRB, Minas Gerais State, Southeastern Brazil (Figure 1). The watersheds and respective fluviometric and pluviometric gauging stations used in the study were: "Fazenda Laranjeiras" $\left(2,087 \mathrm{~km}^{2}\right)$, "Carvalhos" (102 $\left.\mathrm{km}^{2}\right)$, "Bom Jardim" (509 km²), "Aiuruoca" $\left(531 \mathrm{~km}^{2}\right)$, "Fazenda Paraíba" (383 km²), "Andrelândia" $\left(272 \mathrm{~km}^{2}\right)$, "Madre de Deus de Minas" (2,226 km²), and "Lavrinha" $\left(6.76 \mathrm{~km}^{2}\right)$ (Figure 1). 




Figure 1: The geographical location of the Upper Grande River Basin (UGRB) in the Brazilian territory, highlighting the watersheds, sampling points location, fluviometric and pluviometric gauging stations.

The Grande River Basin extends from its source at almost $2200 \mathrm{~m}$ a.s.1, near Itatiaia National Park, in the municipality of Bocaina de Minas, to the mouth of Mortes River at $800 \mathrm{~m}$, in the municipality of Ijaci (Araújo et al., 2018). The Grande River is approximately $240 \mathrm{~km}$ long and $75 \mathrm{~m}$ wide, with an average flow of $312 \mathrm{~m}^{3} \mathrm{~s}^{-1}$ near Camargos hydropower plant (Araújo et al., 2018).

The Aiuruoca River is one of the most important tributaries of the Grande River (Figure 1), and one of the main responsible for maintaining the levels of a sequence of reservoirs of hydroelectric plants (UHEs) installed along its course, being fundamental for the generation of energy in the Southeast region of Brazil.
The climate of the region is classified as Cwa and $\mathrm{Cwb}$, which means the existence of wet and mild summers, and dry and cool winters. The mean annual temperature is approximately $18^{\circ} \mathrm{C}$, with mean minimum and maximum temperatures ranging from $8{ }^{\circ} \mathrm{C}$ to $22{ }^{\circ} \mathrm{C}$, respectively (Mello et al., 2012; Viola et al., 2015). These climatic types allow characterizing a well-defined hydrological year between October of a year and September of a subsequent year.

The UGRB digital elevation model (UGRB-DEM) was obtained from a 1:50,000 contour map at a spatial resolution of $30 \mathrm{~m}$ (IBGE, 1973). The DEM sinks were filled in order to make it hydrologically consistent (Figure 2a). 

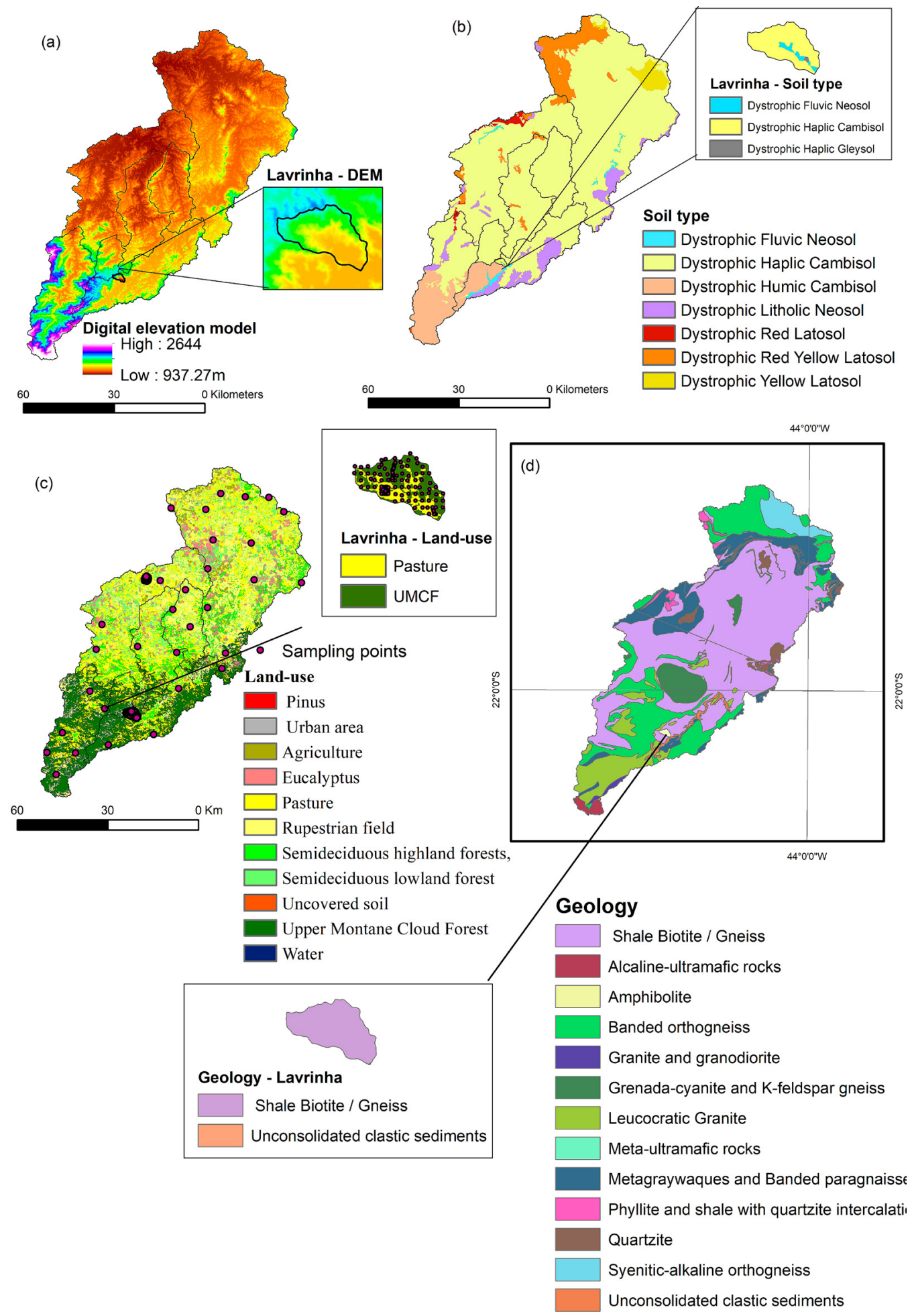

Figure 2: (a) Digital elevation model (IBGE, 1973), (b) soil maps obtained from Araújo (2018) and Menezes et al. (2009), (c) land-use maps of Upper Grande River Basin generated based on satellite imagery obtained by the Landsat ETM+ sensor from the 2013 year, and (d) geology map from CODEMIG (2014). 
The UGRB soil map was obtained from Araújo et al. (2018) and Menezes et al. (2009) on a scale of 1: 10,000. Dystrophic Haplic Cambisols are the main soils, covering $76.8 \%$ of the area, followed by Dystrophic Humic Cambisols (8.0\%), Dystrophic Red Yellow Latosols (6.5\%), Dystrophic Litholic Neosols (5.3\%), Dystrophic Yellow Latosols (1.9\%), Dystrophic Red Latosol (0.8\%), Dystrophic Fluvic Neosols (0.7\%) (Figure 2b).

The land-use map (Figure 2c) was generated based on satellite imagery obtained by the Landsat ETM+ sensor from the 2013 year and processed in the ENVI 4.8 software using supervised classification and the maximum likelihood classifier. The percentages of the land-uses within the UGRB are listed in Table 1.

Table 1: The percentage area of land-use of Upper Grande River Basin.

\begin{tabular}{cc}
\hline Land-use & $\%$ \\
\hline Pasture & 31.55 \\
Rupestrian field (RUF) & 25.05 \\
Upper Montane Cloud Forest & 18.93 \\
(UMCF) & 17.01 \\
Seasonal semideciduous forest (SSF) & 7.08 \\
Agriculture (Ag) & 0.24 \\
Urban area (UA) & 0.14 \\
Water & \\
\hline
\end{tabular}

Table 2 presents the land-use distribution of the eight watersheds inside the UGRB. This procedure was performed for a better characterization of each one of the watersheds.

\section{Saturated soil hydraulic conductivity (Ko)}

The saturated soil hydraulic conductivity reflects the permeability of the soil in depth. In this study, Ko datasets were characterized in situ using a constant flow permeameter (Guelph permeameter - model 2800KI), at 224 points distributed in the Upper Grande River Basin (Figure 1). Firstly, these measurements were carried out between May and October/2009 and complemented in between April and August/2011. Figure 2c shows these points location over the land-use map.

The analysis of variance and the differences between the average Ko values for the watersheds within of UGRB were tested using the SISVAR 5.6 program (Ferreira, 2014). Separation of the average was carried out by the Scott-Knott test with a level of significance of $p<0.05$.

\section{Terrain attributes used for modelling}

A set of 21 terrain attributes (TA) (covariates) were obtained from a digital elevation model (DEM). The DEM is a product of the USGS ASTER sensor obtained from the website https://gdex.cr.usgs.gov/gdex/, with a spatial resolution of $30 \mathrm{~m}$. The DEM was pre-processed to make it hydrologically consistent and used to calculate the terrain attributes (TA).

From the DEM, eighteen topographic indexes were created using the SAGA GIS software (SAGA Development Team version 2.2.2) (Conrad et al., 2015). The following topographic indexes were then calculated: flow direction (fdr), topographic wetness index (twi) (Beven; Kirkby, 1979), slope (Zevenbergen; Thorne, 1987), aspect (Gallant; Wilson, 2000), plan curvature (planc) and profile curvature (profc) (Zevenbergen; Thorne, 1987), cross-section curvature (cros_sec_c), maximum curvature (max_curv), minimum curvature (min_curv), topographic position index

Table 2: The percentage area of land-uses of the watersheds of UGRB.

\begin{tabular}{ccccccccc}
\hline Land-use & $\begin{array}{c}\text { Madre de } \\
\text { Deus }\end{array}$ & $\begin{array}{c}\text { Fazenda } \\
\text { Paraiba }\end{array}$ & $\begin{array}{c}\text { Fazenda } \\
\text { Laranjeiras }\end{array}$ & Carvalhos & $\begin{array}{c}\text { Bom } \\
\text { Jardim }\end{array}$ & Andrelandia & Aiuruoca & Lavrinha \\
\hline UMCF & 16.04 & 10.42 & 21.97 & 53.68 & 57.87 & 2.42 & 64.18 & 62 \\
SSF & 16.61 & 23.63 & 17.44 & 5.95 & 5.22 & 23.22 & 1.54 & $* *$ \\
RUF & 28.57 & 18.06 & 21.31 & 7.19 & 10.15 & 40.12 & 13.35 & $* *$ \\
Water & 0.18 & 0.08 & 0.1 & $* *$ & $* *$ & 0.05 & $* *$ & $* *$ \\
UA & 0.24 & $* *$ & 0.25 & $* *$ & 0.23 & 0.25 & 0.06 & $* *$ \\
Ag & 9.16 & 5.67 & 4.86 & 0.8 & 1.4 & 3.97 & 0.77 & $* *$ \\
Pasture & 29.2 & 42.14 & 34.07 & 32.37 & 25.12 & 29.95 & 20.09 & 38 \\
\hline
\end{tabular}

**nonexistent or $<0.01 \%$ area. 
(tpi) (Guisan; Weiss; Weiss, 1999), texture (Iwahashi; Pike, 2007), convexity, terrain ruggedness index (terr_rug_i), general curvature (gener_curv), surface area (surf_area), multiresolution index of valley bottom flatness (mrvbf) and multiresolution index of ridge top flatness (mrrtf) (Gallant; Dowling, 2003), and automated classifications of topography (Iwahashi pike) (Iwahashi; Pike, 2007).

Using GRASS GIS 7.0 software (Neteler; Mitasova, 2008), another covariate was derived from DEM using the Geomorphons tool. Geomorphons is a mapping tool developed by Jasiewicz and Stepinski (2013) that identifies landforms within a landscape. This tool identifies the 10 most frequent and common landform elements from a typical terrestrial landscape (shoulder, spur, summit, slope, flat, hollow, ridge, foot-slope, valley, and depression) (Jasiewicz; Stepinski, 2013). Geomorphons is based on the concept of local ternary patterns (LTP) (Liao, 2010). In the LTP concept, a neighbor is identified as "1" if its value exceeds the value of the central cell by at least " $t$ ", which is a specified threshold value. A neighbor is labeled "- 1 " if its value to be at least " $t$ " lesser than the value of the central cell; otherwise, the neighbor is labeled "0" (Jasiewicz; Stepinski, 2013). For this study, the Geomorphons was derived from DEM using look up distance (L) of 25 cells (or $250 \mathrm{~m}$ ) and flatness threshold $(t)$ of 1 degree.

\section{Machine learning algorithms for Ko prediction}

Five machine learning algorithms were compared in their performance to predict Ko (Random Forest, Support Vector Machine, Gradient Boosting, Linear Regression, Regularization). The analysis by using the $\mathrm{R}$ package "party" in which "cforest" is included, was used to avoid bias in variable selection with 500 repetitions of 10-fold cross-validation. Explanatory variables (terrain atributes) in this study vary from continuous to categorical, and with categorical variables containing various numbers of categories (Strobl et al., 2007). The analysis without variable selection also was tested. The models' performance was computed based on the adjusted coefficient of determination (adjusted $\mathrm{R}^{2}$ ).

Random Forest (RF) model is a non-parametric technique that has been successfully applied to soil properties prediction (Wiesmeier et al., 2011; Castro Franco et al., 2015; Hengl et al., 2015; Chagas et al., 2016; Yang et al., 2016; Dharumarajan; Hedge; Singh, 2017; Silva et al., 2017; Blanco et al., 2018; Wang et al., 2018a). The model combines a set of decision trees to improve the accuracy of prediction of a given environmental variable, where each tree is generated by bootstrap samples (random sampling with substitution), leaving one-third of training samples, called Out-of-Bag (OOB) data, for using in the model's performance evaluation (Breiman, 2001; Liaw; Wiener, 2002).

The Support Vector Machine (SVM) is a machine learning algorithm, which consists in the construction of a hyperplane for the ideal separation between the classes of a data set (Hastie; Tibshirani; Friedman, 2009). This distance between the hyperplane and the first point of each class is often called the margin. The SVM algorithm defines each point belonging to one of the classes and provides the maximum margin of the possibility of the point belonging to one of them (Ocak; Seker, 2013).

Gradient Boosting is a machine learning that utilizes decision trees as the weak learner to generate a prediction model in gradient boosting (Friedman, 2001). Within the model, a new regression tree is trained at each iterative step to optimize certain loss functions identified by the steeper gradient (Lawrence et al., 2004).

Linear regression models are used for continuous predictor responses and result in interpretable description of relationships between predictor variables and responses of interest. In this context, the model aims to learn the weights (or parameters) of the equation, which best describes the relationship between predictors and a variable response to use in prediction (Hastie; Tibshirani; Friedman, 2009).

The regularization is applied to obtain biased estimators, but with reduced variance, for the linear regression model parameters. Regularization imposes penalties on the complexity of the predictive model and thus contributes to the reduction of the overfitting effect and, consequently, to the improvement of the model's predictive performance in new observations (Hastie; Tibshirani; Friedman, 2009).

\section{Validation of Ko results based on the hydrologic indicators}

To validate the models from a hydrological point of view, Ko is essential as a soil hydrology attribute that strongly influence the soil-water infiltration, and thus, in the catchment hydrology (Pinto et al., 2017). Basically, the greater Ko the greater baseflow as the latter is controlled by the water infiltration and movement in the soil profile (Zomlot et al., 2015; Pinto et al., 2015; 2017).

Further validation of the land-use and Ko relationships in UGRB was performed based on hydrological indicators from eight watersheds (Figure 1), with sizes varying from $6.5 \mathrm{~km}^{2}$ to $2100 \mathrm{~km}^{2}$, occupying different positions in the landscape. These indicators were the ratio between baseflow and runoff $(\mathrm{BF} / \mathrm{R})$, and 
overland flow and runoff $(\mathrm{OF} / \mathrm{R})$. The overland flow was determined by the difference between runoff and baseflow.

These hydrological indicators were developed based on rainfall and fluviometric long-term series taken from the Hydrological Information System of the National Water Agency (ANA) (HIDROWEB, 2018) in the period between 1992 and 2002, except for Lavrinha Watershed (Figure 2), which was monitored between 2006 and 2012 (Mello et al. 2012). The studied hydrological years covered the period between October of a year to September of a subsequent year, capturing both the ascension and recession phases of the hydrograph.

Baseflow was obtained through Barnes' method by means of characterization of the hydrograph recession inflex point (Barnes, 1939; Durães; Mello, 2013; Hingray; Picouet; Musy, 2014). This method considers an exponential behavior for the baseflow based on the identification of inflection points in hydrographs, following the fundamentals of the Maillet equation (Tallaksen, 1995), widely used to model the baseflow behavior (Equation 1):

$\mathrm{Q}_{\mathrm{t}}=\mathrm{Q}_{0} \exp (-\alpha . \mathrm{t})$

Where $\mathrm{Q}_{0}$ is the initial baseflow rate, $\mathrm{Q}_{\mathrm{t}}$ is the baseflow rate at time $t$ (daily) and $\alpha\left(\right.$ day $\left.^{-1}\right)$, the recession coefficient.

The baseflow/runoff $(\mathrm{BF} / \mathrm{R})$ and overland flow/ runoff $(\mathrm{OF} / \mathrm{R})$ ratios were determined so that allow quantifying the participation of the baseflow as it is a direct consequence of groundwater recharge (Pinto et al., 2017). Both indicators are influenced by Ko behavior, as above commented.

\section{RESULTS AND DISCUSSION}

\section{Saturated soil hydraulic conductivity (Ko) data from the land uses different sampling approaches}

Table 3 presents the average and standard deviation of the Ko values for each land-use in UGRB.

These results indicate significant variability in the measured Ko in different land-uses of UGRB (Table 3 and Figure 3). This high Ko variability occurs due to the different extrinsic factors, including geomorphic surface, weather, land-use, land management, and intrinsic soil properties, such as soil structure and bulk density (Pachepsky et al., 2008; Sobieraj et al., 2002; Zimmermann et al., 2013).
Table 3: Average and standard deviation of Ko for each land-use of UGRB.

\begin{tabular}{ccc}
\hline Land-use & Ko average $\left(\mathrm{m} \mathrm{day}^{-1}\right)$ & $\begin{array}{c}\text { Ko standard } \\
\text { deviation }\left(\mathrm{m} \mathrm{day}^{-1}\right)\end{array}$ \\
\hline UMCF & 2.18 & 3.67 \\
SSF & 0.92 & 1.64 \\
RUF & 0.84 & 2.25 \\
Ag & 0.52 & 0.49 \\
Pasture & 0.79 & 1.14 \\
\hline
\end{tabular}

It is to be expected that areas with higher Ko are associated with the presence of native forest, considering the same pedological unit (Menezes et al., 2016, 2018; Pinto et al., 2015). It is also important to note that remnants of native forests (Atlantic Forest) in southeastern Brazil are mostly found in areas with the steepest relief, not prone to agriculture (Silva et al., 2007) such as the steep hills and mountainous areas like UGRB region.

The influence of land-use on Ko values can be linked with the importance of the native forest in water dynamics in the soil profile, mainly in soils of the headwater regions. In such soils, the contribution of organic matter can promote significant improvements on soils' structure, like the arrangements of the aggregates and their connectivity leading to preferential flows networks (Kay, 1998; Six et al., 2000; Tisdall; Oades, 1982; Tisdall, 1996). Comparatively, areas with tramped pasture, which are very common in UGRB (Figure 2c), have shown lower Ko values and greater overland flow, reducing the infiltration and the groundwater recharge (Alvarenga et al., 2011; Menezes et al., 2016, 2018). These features were well demonstrated based on field measurements and over samples under micromorphological analyzes (Pinto et al., 2016, 2017). Jarvis et al. (2013) and Jorda et al. (2015) found a stronger relationship between Ko and land-use, organic carbon content and bulk density. Zimmermann, Elsenbeer and Moraes, (2006) observed a decrease in the soil hydraulic conductivity and consequently increase of the frequency and volume of overland flow due to the conversion of native forest into the pasture in the Amazon forest. Yet, similar results were also obtained by Zimmermann and Elsenbeer (2008), who observed Ko at the depths of 12.5, 20 and $50 \mathrm{~cm}$ with a constant head permeameter in the Eastern Cordillera of the Andes of southern Ecuador. They attributed the reduced permeability under the Ecuadorian pasture to the effect of soil compaction caused by cattle treading. 


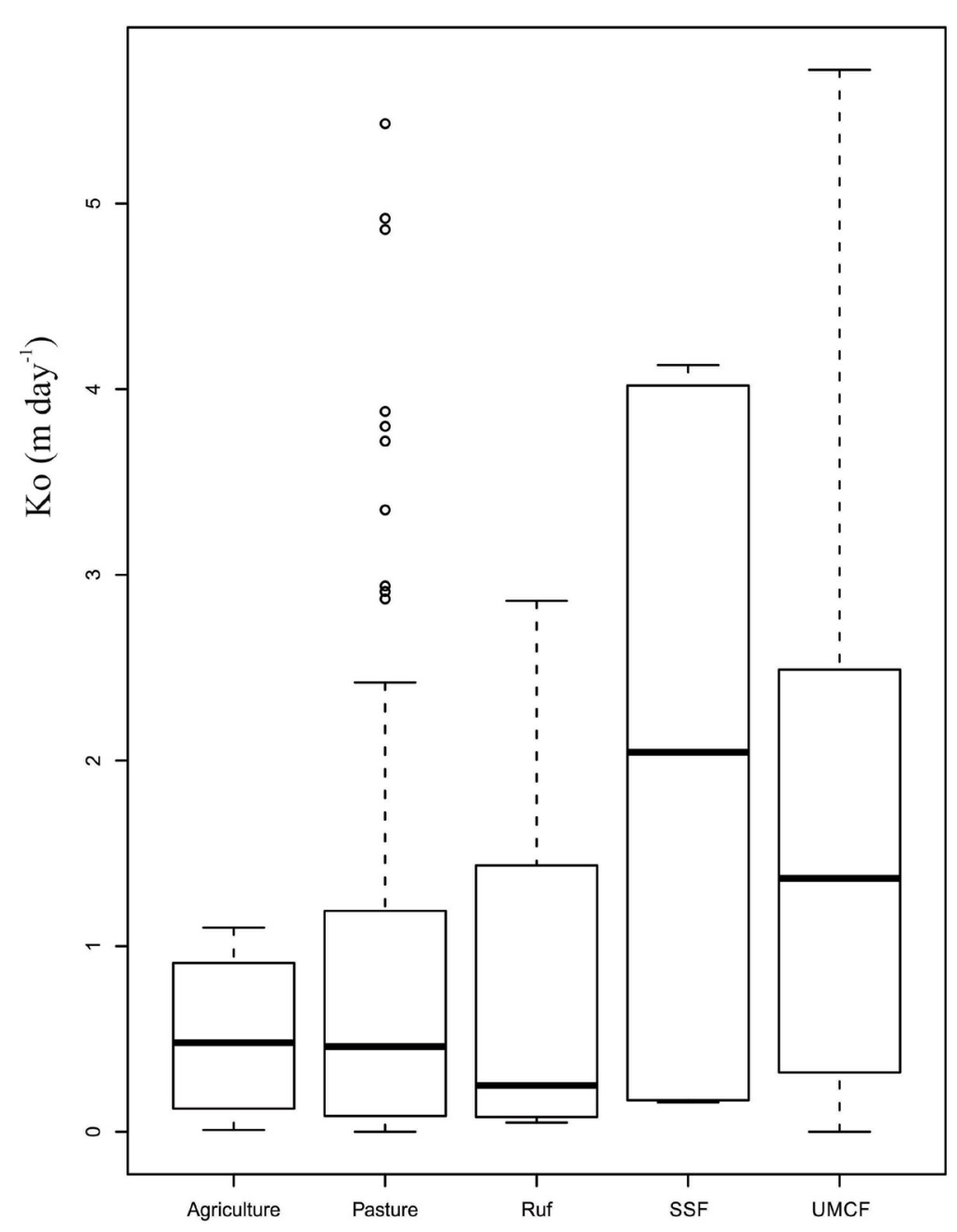

Figure 3: Box plot comparison of Ko data from the five land-use. Horizontal bars indicate the observed mean Ko value. Abbreviations Ruf, SSF, and UMCF refer to the Rupestrian Field, Seasonal semideciduous forest, and Upper Montane Cloud Forest (Dense Ombrophilous Forest), respectively.

Using a conceptual hydrological model, Viola et al. (2014) simulated possible impacts on the hydrology of the UGRB based on different land-use scenarios. Their results for the simulated flow demonstrated a strong sensitivity between land-use and water balance in this basin. Agricultural and planted forest have directly affected the water balance at studied watersheds, which may compromise the water yield capacity as well as the natural streamflow regulation capacity of UGRB. This type of study confirms that, even in simulations, the behavior of land-use against the hydrological regime of the basin remains.

Previous studies have shown (on a small scale) a strong relationship of land-use with the soil hydrological properties. Pinto et al. (2017) modeled the spatial prediction of the soil drainage porosity by Fuzzy Logic in a small watershed located in southern UGRB. The performance of their model significantly increased when land-use was taken into account, strengthening that, in headwater regions, the land-use has a strong relationship with the soil hydrological properties.

The geology influence on Ko values was also approached (Figure 2d). The geology of UGRB is complex, and its rocks have been metamorphosed, bent and raised several times over the billions of years since their formation (Araújo et al., 2018). Although most rocks of the UGRB are quite fractured, their permeability and flow are moderate or even low (CETEC, 1983). For this reason, the C horizon of the soils assumes great importance in maintaining the quality and abundance of water in this basin (Araújo et al., 2018). 
In the northern UGRB, there is a predominance of Dystrophic Yellow Latosols and Dystrophic Red Yellow Latosols (Figure 2c). It is well known that Oxisols have better physical conditions for water infiltration and percolation, influenced primarily by the aggregate stability (Ferreira; Fernandes; Curi, 1999; Reatto et al., 2007; Ajayi et al., 2009; Resende et al., 2014). However, even with adequate water percolation capacity due to their genesis, these soils can present reduced infiltration capacity if inadequate landuse and management take place, such as overstocking in livestock production. In addition, the geology of these areas can contribute to the low Ko values. Chagas et al. (1997) and Skorupa et al. (2016) studied two contrasting Oxisols in Minas Gerais, Brazil, and reported that the orientation of their parent material layers had great influence on drainage of those soils. They observed that the orientation of metaphelitic rock layers interferes with soil drainage. In situations where such orientation is horizontal (Red-Yellow Latosols and Yellow Latosols) there is a more restricted drainage. Where

$44^{\circ} 50^{\prime} 0^{\prime \prime W} \quad 44^{\circ} 40^{\prime} 0^{\prime \prime W} \quad 44^{\circ} 30^{\prime} \mathrm{O}^{\prime \prime} \mathrm{W} \quad 44^{\circ} 20^{\prime} 0^{\prime \prime} \mathrm{W} \quad 44^{\circ} 10^{\prime} 0^{\prime \prime} \mathrm{W} \quad 44^{\circ} 0^{\prime} \mathrm{O}^{\prime \prime} \mathrm{W} \quad 43^{\circ} 50^{\prime} \mathrm{O} \mathrm{W} \mathrm{W}$

(a)

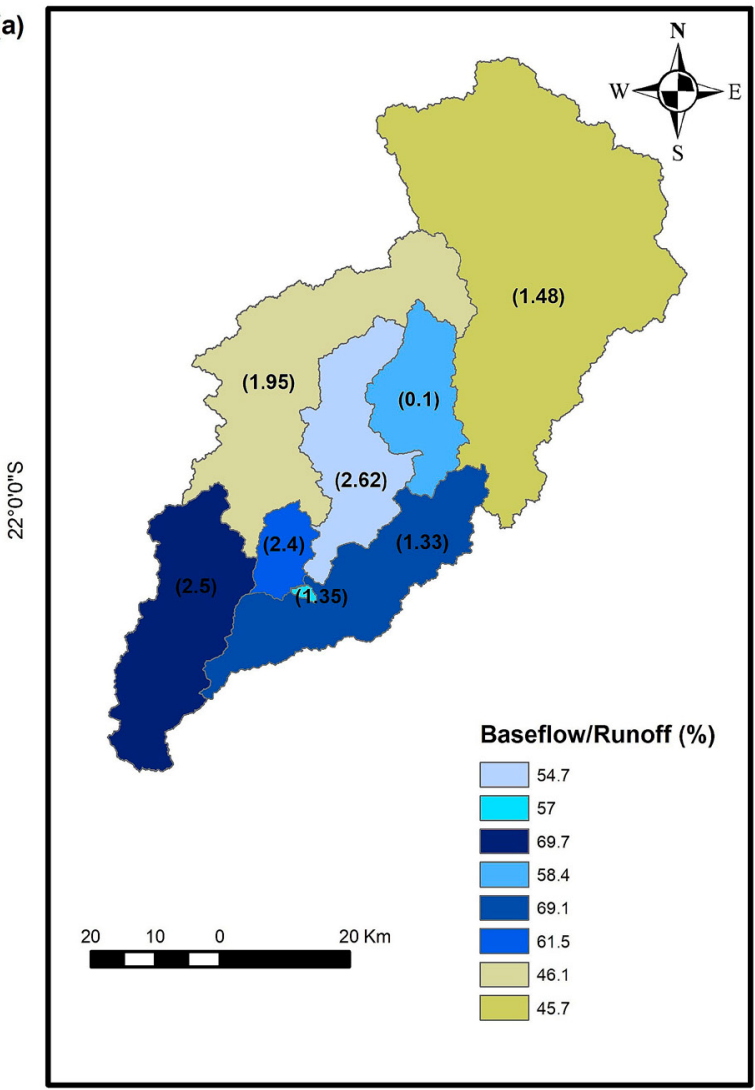

the orientation of the layers is inclined (Red Latosols), water infiltration is facilitated and provides better drainage in the Red Latosols with greater "solum" thickness (Chagas et al., 1997; Skorupa et al., 2016).

In the southern part of UGRB the lithological unit is fractured (Gneiss) (Figure 2d) (CETEC, 1983) thus contributing to the water storage and transmittance that could be limited if the permeability and flow are moderate or low in within the fracturated rocks.

\section{Spatial distribution of hydrological indicators in UGRB}

Figure 4 presents maps that show spatial distribution of the hydrological indicator baseflow/runoff (BF/R).

Further understanding the behavior of the $\mathrm{BF} / \mathrm{R}$ in UGRB, we selected three watersheds being Aiuruoca and Bom Jardim with the highest BF/R values and Madre de Deus with the lowest value (Figure 4a). Then, we compared with the land-use map (Figure 4b). $44^{\circ} 50^{\prime} 0^{\prime \prime W} \quad 44^{\circ} 40^{\prime} 0^{\prime \prime W} \quad 44^{\circ} 30^{\prime} \mathrm{O}^{\prime \prime} \mathrm{W} \quad 44^{\circ} 20^{\prime} 0^{\prime \prime} \mathrm{W} \quad 44^{\circ} 10^{\prime} 0^{\prime \prime W} \quad 44^{\circ} 0^{\prime} 0^{\prime \prime W} \quad 43^{\circ} 50^{\prime} 0^{\prime \prime} \mathrm{W}$

(b)

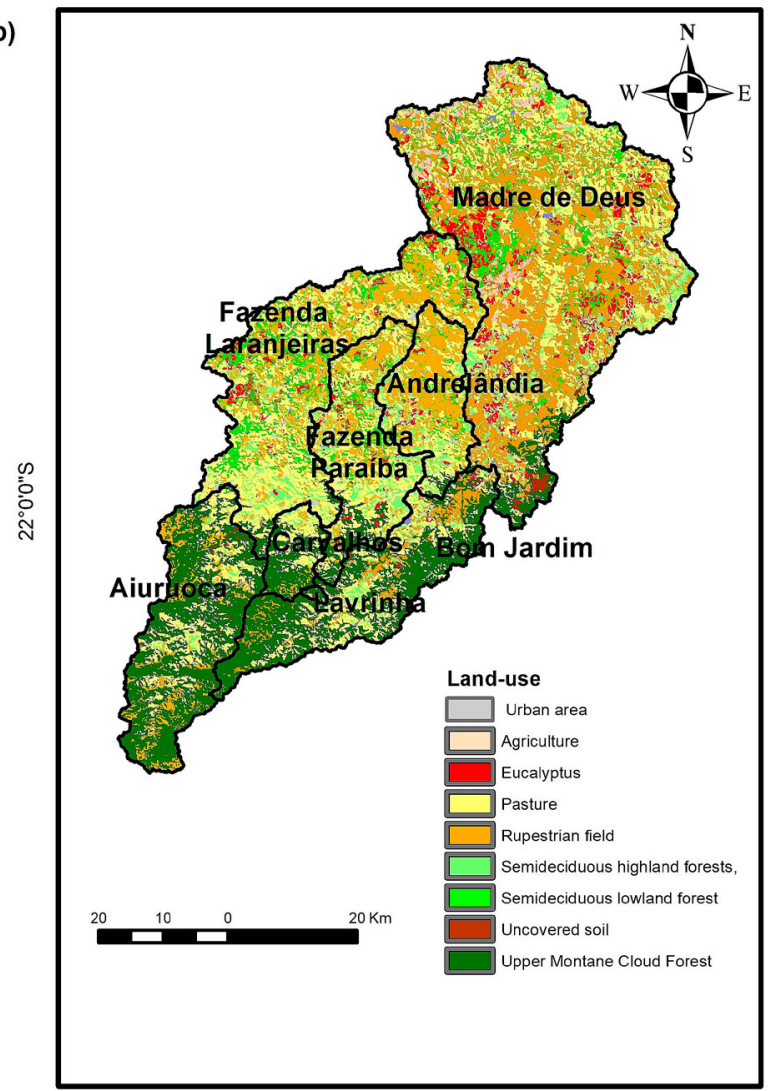

Figure 4: (a) Spatial distribution of the hydrological indicator baseflow/runoff in each watershed of the Upper Grande River Basin (In parentheses Ko values in $\mathrm{m} \mathrm{day}^{-1}$ ). (b) Land-use map of watersheds within of UGRB. 
We can observe greater $\mathrm{BF} / \mathrm{R}$ values towards to southern watersheds (Aiuruoca and Bom Jardim) (Figure 4a), where there is a predominance of the Dense Ombrophilous Forest (Upper Montane Cloud Forest) (Figure $4 \mathrm{~b}$ ). Otherwise, the lower BF/R value was found in Madre de Deus watershed where predominant land-use is rupestrian field and pastures (Figure $4 \mathrm{~b}$ and Table 2). Therefore, there is a significant correspondence between $\mathrm{BF} / \mathrm{R}$ and land-use indicating that the hydrological indicators were sensitive to land-use changes in the watersheds. The identification of areas more prone to base flow in a basin is important for the implementation of management actions more appropriate to these areas aiming to reduce the overland flow.

Menezes et al. (2009), in a hydrological study carried out in paired catchments (forested and pastured) within Lavrinha Creek Watershed (Figure 2c), verified that under native forest (Dense Ombrophilous Forest) the $\mathrm{BF} / \mathrm{R}$ ratio was much greater. They attributed it to the contribution of organic matter to the soil (Cambisol), which favor the water infiltration due to both greater permeability and connectivity of the pores of the soil. Previous studies investigated the role of shallow Cambisols linked to the land-use changes in the streamflow behavior of the Mantiqueira Range region using micromorphological image analysis (Pinto et al., 2015; 2018). Their results clearly showed that forested soils have a more open and heterogeneous pore network structure probably linked to the biological activities and high root-activity, which resulted in increased rates of water infiltration, as well as increased soil hydraulic conductivity. In addition, the native forest has a significant role in the protection of the ground against direct raindrop impacts, thus reducing the overland flow and sediment transport, and offering better conditions for water movement into the soil profile (Archer et al., 2013; Bonell et al., 2010; Hao et al., 2019; Hümann et al., 2011; Menezes et al., 2009).

In Andrelândia and Bom Jardim watersheds, there are lower Ko values when the soils, predominantly shallow Dystrophic Haplic Cambisol followed by Dystrophic Litholic Neosol, are associated with agriculture, pasture, and rupestrian field (Figures $2 \mathrm{~b}$ and $2 \mathrm{c}$ ).

With the same approach as for $\mathrm{BF} / \mathrm{R}$ data, we selected three watersheds as following (Figure $4 b$ ): Fazenda Paraíba and Aiuruoca with the highest Ko values, and Andrelândia with lower Ko value (Figure 4a). Then, we compared with the respective land-use map.

We can observe higher Ko values towards to southern UGRB (Aiuruoca), where there is a predominance of the UMCF. In addition, lower Ko values were found to
Andrelândia watershed where rupestrian field and pasture are (Figure $4 \mathrm{~b}$ and Table 2). It is important to stress that the pastures in this basin do not have adequate management, being mostly degraded areas, mainly if combined with shallow soils, e.g. the Dystrophic Haplic Cambisols and Dystrophic Litholic Neosols (Figure 2b).

Otherwise, in Fazenda Paraíba watershed where the highest average Ko is obtained, there is no predominance of native forests as land use (Figure $8 \mathrm{~b}$ and Table 2), however, such Ko values could also be linked to the fragments of seasonal semideciduous forest (Figure $4 b$ ).

Zimmermann, Elsenbeer and Moraes (2006) investigated the effects of land-use in areas of the Amazon basin and found the greatest reduction in percolation in areas with pasture. The authors attribute these results to the soil compaction by grazing. Therefore, the land-use and management factors are crucial to maintaining the water regime, especially in headwater watersheds.

\section{Models performance}

Figure 5 and 6 present the models performance with and without variable selection, respectively.

All the tested methods (Figure 5 and 6) resulted in a relatively low $\mathrm{R}^{2}(\sim 30 \%)$, with support of vector machine and random forest yielding slightly better results than the other tested methods. These results is probably due the high spatial variability of the saturated soil hydraulic conductivity. In this sense, it is important to highlight that the use of terrain attributes and land-use can help to model about $30 \%$ of the Ko variation. This is relevant especially for developing countries, where field-collected data is very sparse and resources for wider points sampling is very limited. In addition, it is possible that if a finer resolution of the DEM could be provide better results since the locations where the Ko was determined are punctual and our model is based on a $30-\mathrm{m}$ resolution. It is well known that Ko has a very great spatial variability even in small distances.

\section{Relationship between hydrological indicators and land-uses in UGRB watersheds}

Figure 7 presents the precipitation-runoff rates from each watershed of the UGRB.

It is possible to observe a greater both precipitation and runoff in Lavrinha watershed (Figure 7), since this watershed is located in the south part of the UGRB, in the Mantiqueira Range (mountainous and strong undulated relief) (Figue 1). This part of the UGRB region is very susceptible to water erosion, which demands special concerns related to land-use and management (Pinto et al., 2018). Because of this, a better understanding of the 


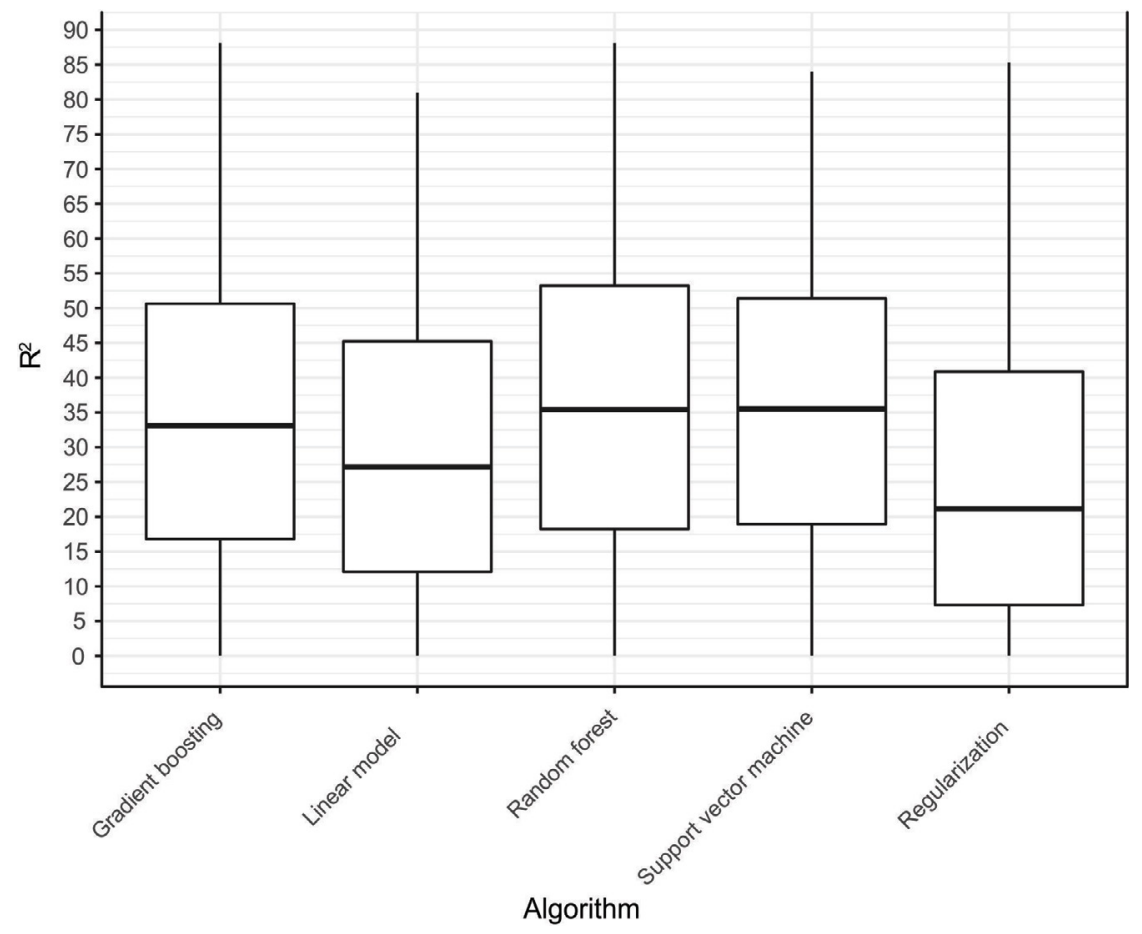

Figure 5: Boxplot of $\mathrm{R}^{2}$ obtained from 100 repetitions of 10 -fold cross-validation for assessing the performance of models predicting Ko based on terrain attributes and land use, with the variable selection.

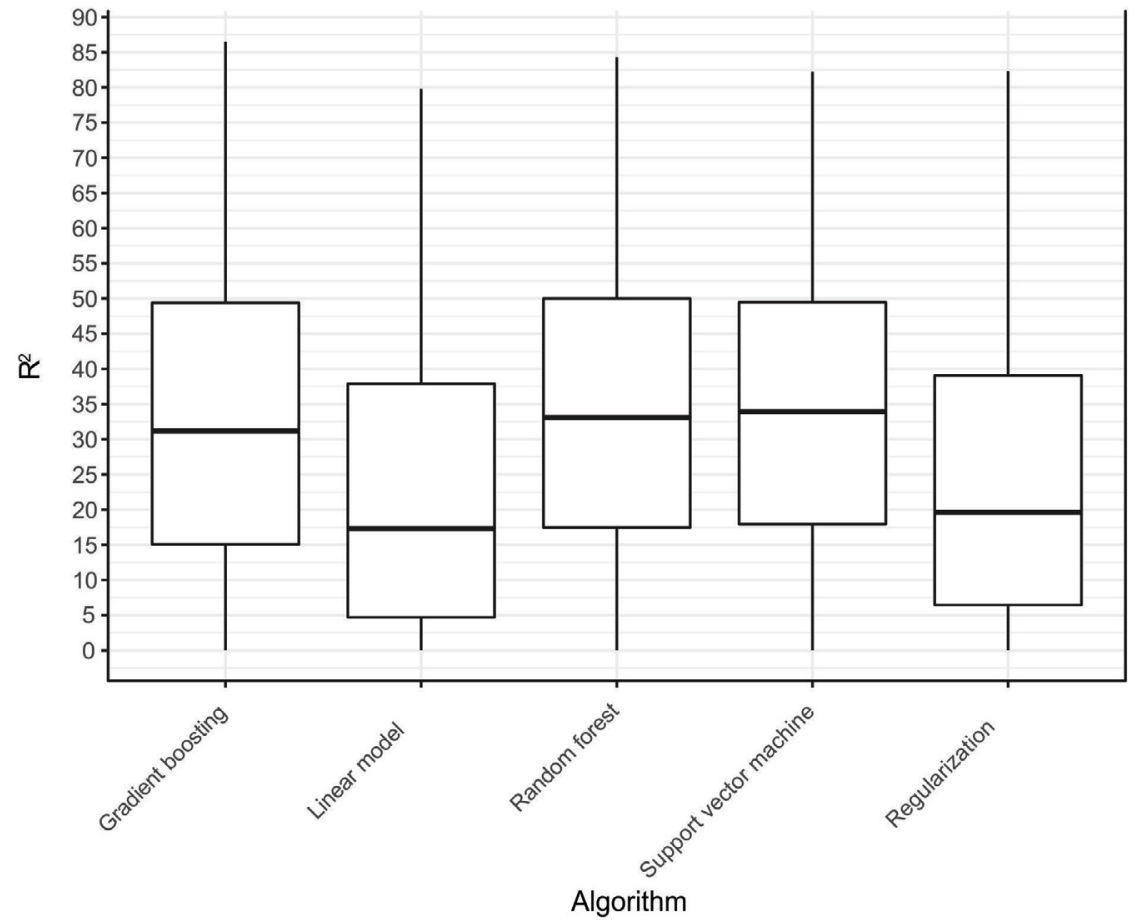

Figure 6: Boxplot of $\mathrm{R}^{2}$ obtained from 100 repetitions of 10 -fold cross-validation for assessing the performance of models predicting Ko based on terrain attributes and land use, without variable selection. 
relationships between hydrological indicators and land-use are necessary to better and more successful decision making for soil-water conservation and management targeting.

Figure 8 presents the average hydrological indicators of the watersheds within the UGRB (Figure 1) along with the average Ko values observed inside each watershed.

Despite Ko did not show statistical significant differences among the watersheds (Figure 8), we can be observe great differences in the average values, highlighting Aiuruoca, Carvalhos and Fazenda Laranjeiras, which presented the highest values. In this sense, an important relationship between the hydrological flow indicators and land-uses was also observed in the context of these watersheds of UGRB. The $\mathrm{BF} / \mathrm{R}$ ratio was greater for the watersheds Aiuruoca (69.7\%), Bom Jardim (69.1\%), Carvalhos (61.5\%), and Lavrinha $(57.0 \%)$ respectively, consequently, a lesser contribution of overland flow to the total runoff (OF/R). In addition, Aiuruoca has a greater native forest (Dense Ombrophilous Forest + Seasonal Semideciduous Forest) area $(65.7 \%)$, followed by Bom Jardim (63.1\%), Lavrinha (62\%), and Carvalhos (59.6\%) (Figure 8). A lower BF/R ratio (Figure 7) was found to Madre de Deus de Minas (45.7\%), Fazenda Laranjeiras (46.1\%), and Fazenda Paraíba $(54.3 \%)$, meaning a greater contribution of

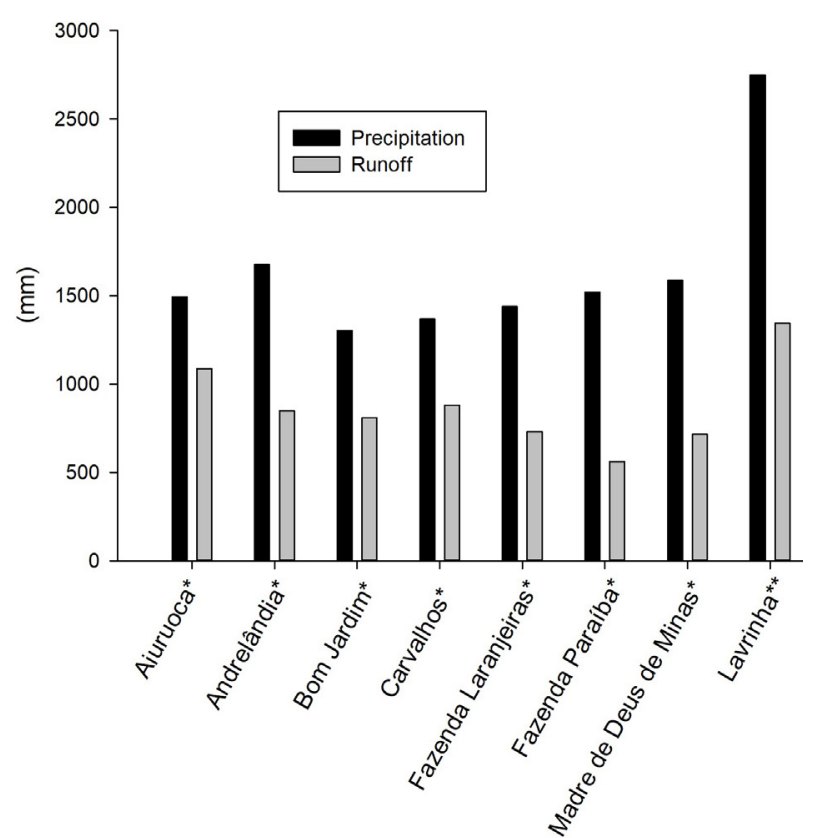

Figure 7: Precipitation and runoff rates from the watersheds within the UGRB.

*Average value from 1992/1993 to 2001/2002 hydrological years; ** for the hydrological years of $2009 / 2010$ to 2010/2011. overland flow to the total runoff in these areas and less water percolation. Therefore, these results corroborate the hypothesis that the land-use has a greater influence on the hydrologic properties of the soils in these watersheds, with consequences to the streamflow behavior.

Based on these results, we can state that there is an intrinsic relationship between land-use and hydrological flow indicators of the watersheds. These results are linked to the influence of the native forest, highlighting the interaction between interception and the direct impact of
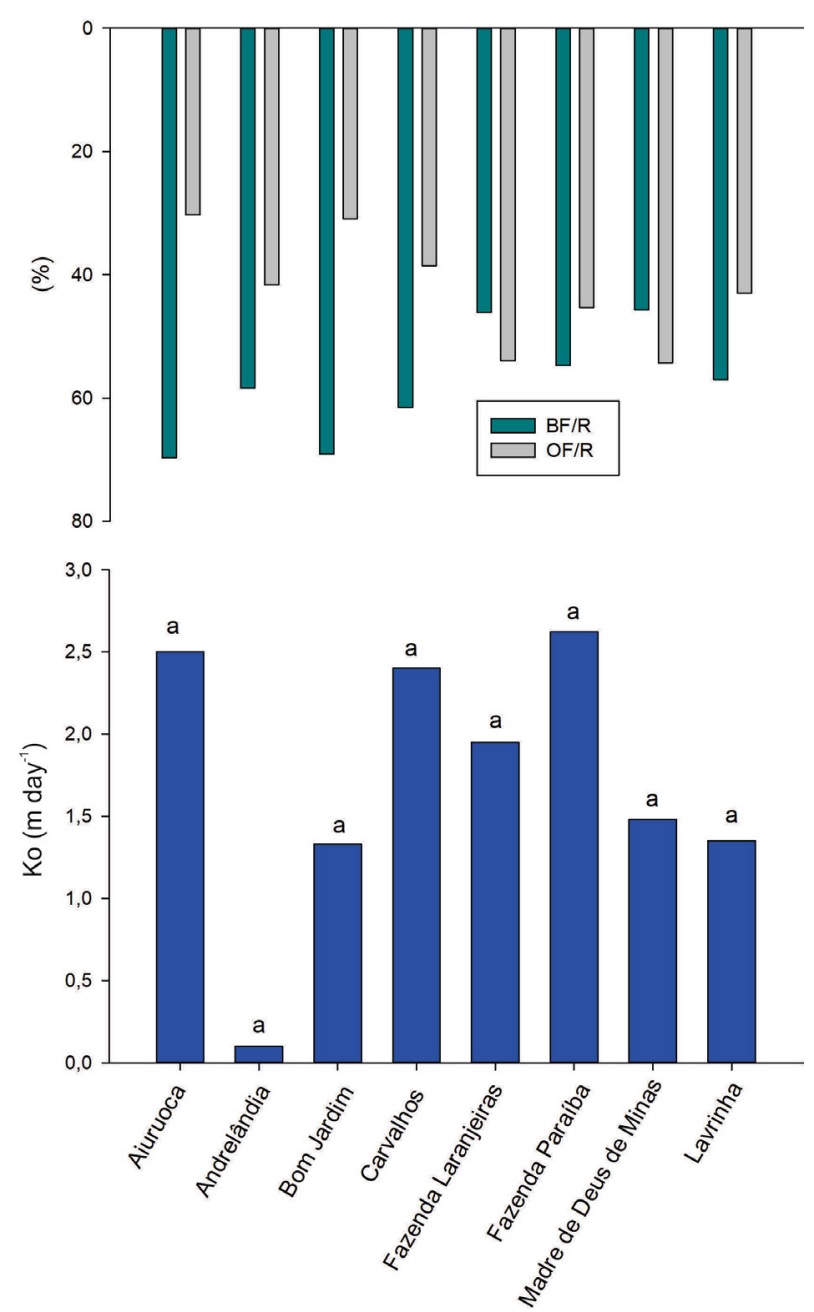

Figure 8: Hydrological indicators and average Ko values observed from the watersheds within the UGRB (see Figure 1). Ko: saturated soil hydraulic conductivity (m day ${ }^{-1}$ ); BF/R: baseflow/runoff; OF/R: overland flow/ runoff.

Average Ko values followed by the same letter are not significantly different at the 0.05 probability level within each sub-basin, according to Scott-Knott test. 
rainfall on the soil surface, and the saturated soil hydraulic conductivity (Pinto et al., 2018). Mello et al. (2019) evaluating the intrinsic relationship between hydrology, soil, and forest in a tropical montane cloud forest (TMCF) inside Lavrinha watershed observed that baseflow was the main hydrological element in this site. It is able to maintain the streamflow, not only during the recession phase but also for longer periods, especially during prolonged droughts.

Price, Jackson and Parker, (2010) characterized some soil physical properties under forest, pasture, and managed lawn in the southern Blue Ridge Mountains of southwestern North Carolina, USA. They concluded that the conversion of forest into other land-use types, such as pasture and lawn, reduced the soil infiltration capacity, increasing the overland flow, and deeply changing the natural water dynamics in the watershed.

Owuor et al. (2018) evaluating the effects of land-use on the soil infiltration in the Sondu basin, western Kenya, Africa, observed lesser soil hydraulic conductivity in the pasture than in natural forest soils due to soil compaction by animal trampling. The authors also attributed the changes in landscape water fluxes, discharge patterns of rivers and groundwater recharge rates to the land-use changes in the watershed.

These results demonstrate how maintenance of native forests play a fundamental role for water movement in the soil profile in the UGRB headwaters, emphasizing that the conservation of adequate soil cover, preferably native forest in headwaters, will promote greater hydrological sustainability (Bonell et al., 2010; Pinto et al., 2015).

\section{CONCLUSIONS}

There is a significant correspondence between the hydrological indicator baseflow/runoff and land-use showing that this hydrological indicator was sensitive to land-use changes in the watersheds. The highest Ko values were associated with native forest and the least ones associated with pasture and rupestrian field. This research also suggested that deforestation of the native forest of the UGRB can reduce the Ko, thus decreasing soil water infiltration, groundwater recharge, and water storage capacity. This behavior can increase the surface runoff, the impacts from soil erosion on water yield, and its quality. Therefore, deforestation in the UGRB should not be considered for planning and management of the water resources as the areas with higher Ko values are associated with native forest fragments, demonstrating the importance of the native forest in the groundwater recharge in the UGRB region. The tested methods for predicting saturated soil hydraulic conductivity resulted in a relatively low $\mathrm{R}^{2}$ due the high spatial variability of the soil hydraulic conductivity and the non-existence of a DEM with finer resolution than 30-m, becoming Ko spatial modeling a hard task.

\section{ACKNOWLEDGMENTS}

This study was financed in part by the Coordenação de Aperfeiçoamento de Pessoal de Nível Superior - Brasil (CAPES) - Finance Code 001. The authors also gratefully acknowledge the following funding Brazilian research agencies: CNPq and FAPEMIG. We also wish to thank Dr. Vinícius Augusto de Oliveira for support in the land-use map and Dr. Teotônio Soares de Carvalho for support in machine learning algorithms.

\section{REFERENCES}

AJAYI, A. E. et al. Relation of strength and mineralogical attributes in Brazilian latosols. Soil and Tillage Research, 102(1):14-18, 2009.

ALVARENGA, C. C. et al. Continuidade espacial da condutividade hidráulica saturada do solo na bacia hidrográfica do Alto Rio Grande, MG. Revista Brasileira de Ciência do Solo, 35(5), 1745-1757, 2011.

ARAÚJO, A. R. de. et al. Geomorfologia, solos e aptidão agrícola das terras da bacia do alto Rio Grande, Minas Gerais. Lavras: Editora UFLA, 2018. 237p.

ARCHER, N. A. L. et al. Soil characteristics and landcover relationships on soil hydraulic conductivity at a hillslope scale: A view towards local flood management. Journal of Hydrology, 497:208-222, 2013.

BARNES, B. S. The structure of discharge recession curves. Transactions of American Geophysical Union, 20(2):721-725, 1939.

BEVEN, K. J.; KIRKBY, M. J. A physically based, variable contributing area model of basin hydrology. Hydrological Sciences Bulletin, 24(1):43-69, 1979.

BEVINGTON, J. et al. On the spatial variability of soil hydraulic properties in a Holocene coastal farmland. Geoderma, 26:294-305, 2016.

BLANCO, C. M. G. et al. Spatial prediction of soil water retention in a páramo landscape: Methodological insight into machine learning using random forest. Geoderma, 316:100-114, 2018.

BONELL, M. et al. The impact of forest use and reforestation on soil hydraulic conductivity in the western ghats of India: Implications of surface and sub-surface hydrology. Journal of Hydrology, 391(1-2):47-62, 2010. 
BREIMAN, L. Random forests. Machine Learning, 45(1):5-32, 2001

CAMERA, C. et al. A high resolution map of soil types and physical properties for Cyprus: A digital soil mapping optimization. Geoderma, 285(1):35-49, 2017.

CASTRO FRANCO, M. et al. Prediction of soil properties at farm scale using a model-based soil sampling scheme and random forest. Soil Science, 180(2):1-12, 2015.

CENTRO TECNOLÓGICO DE MINAS GERAIS - CETEC. Diagnóstico Ambiental do Estado de Minas Gerais. Belo Horizonte: Editora CETEC, 1983. 158p.

CHAGAS, C. S. et al. Orientação das camadas de rochas metapelíticas pobres na gênese de Latossolos sob Cerrado. Pesquisa Agropecuária Brasileira, 32(5):539-548, 1997.

CHAGAS, C. D. S. et al. Spatial prediction of soil surface texture in a semiarid region using random forest and multiple linear regressions. Catena, 139:232-240, 2016.

COMPANHIA DE DESENVOLVIMENTO ECONÔMICO DE MINAS GERAIS - CODEMIG. Mapa geológico do estado de Minas Gerais. Belo Horizonte: CODEMIG, 2014. Escala 1:1.000.000. Available in: <http://codemig.com.br>. Access in: August, 30, 2019.

CONRAD, O. et al. System for Automated Geoscientific Analyses (SAGA) v. 2.1.4. Geoscientific Model Development, 8(7):1991-2007, 2015.

COSTA, A. M. et al. Groundwater recharge potential for sustainable water use in urban areas of the Jequitiba River Basin, Brazil. Sustainability, 11(10):1-20, 2019.

DHARUMARAJAN, S.; HEDGE, R.; SINGH, S. K. Spatial prediction of major soil properties using Random Forest techniques $\mathrm{e}$ a case study in semi-arid tropics of South India. Geoderma Regional, 10:154-162, 2017.

DURÃES, M. F.; MELLO, C. R. Groundwater recharge behavior based on surface runoff hydrographs in two basins of the Minas Gerais state. Revista Ambiente \& Água, 8(2):5766, 2013.

FERREIRA, M. M.; FERNANDES, B.; CURI, N. Mineralogia da fração argila e estrutura de Latossolos da região sudeste do Brasil. Revista Brasileira de Ciência do Solo, 23(1):507514, 1999.

FERREIRA, D. F. Sisvar: A Guide for its Bootstrap procedures in multiple comparisons. Ciência e Agrotecnologia, 38(2):109-112, 2014.

FRIEDMAN, J. H. Greedy function approximation: A gradient boosting machine. Annals of Statistics, 29:1189-1232, 2001.
GALLANT, J. C.; WILSON, J. P. Primary topographic attributes. In: WILSON, J. P.; GALLANT, J. C. (Eds.), Terrain Analysis: Principles and applications. New York: John Wiley \& Sons, p.51-85, 2000.

GALLANT, J. C.; DOWLING, T. I. A multiresolution index of valley bottom flatness for mapping depositional areas. Water Resources Research, 39:1347-1359, 2003.

GERMER, S. et al. Influence of land-use change on near-surface hydrological processes: Undisturbed forest to pasture. Journal of Hydrology, 380(3-4):473-80, 2010.

GUISAN, A.; WEISS, S. B.; WEISS, A. D. GLM versus CCA spatial modeling of plant species distribution. Plant Ecology, 143(1):107-122, 1999.

GWENZI, W. et al. Field scale spatial variability of saturated hydraulic conductivity on a recently constructed artificial ecosystem. Geoderma, 166(1):43-56, 2011.

$\mathrm{HAO}$, M. et al. Impacts of changes in vegetation on saturated hydraulic conductivity of soil in subtropical forests. Scientific Reports, 9(1):8372, 2019.

HASTIE, T.; TIBSHIRANI, R.; FRIEDMAN, J. The Elements of Statistical Learning: Data mining, inference, and prediction. Berlin, BE: Springer, 2009. 745p.

HENGL, T. et al. Mapping soil properties of Africa at $250 \mathrm{~m}$ resolution: Random forests significantly improve current predictions. PLoS One, 10(6):e0125814, 2015.

HIDROWEB. Banco de dados. Available in: <http://hidroweb. ana.gov.br> Access in: August, 30, 2018.

HINGRAY, B.; PICOUET, C.; MUSY, A. Hydrology: A science for engineers. CRC Press, Boca Raton, 2014. 592p.

HÜMANN, M. et al. Identification of runoff processes - The impact of different forest types and soil properties on runoff formation and floods. Journal of Hydrology, 409(34):637-649, 2011.

INSTITUTO BRASILEIRO DE GEOGRAFIA E ESTATÍ́STICA. IBGE. Carta do Brasil. Rio de Janeiro, 1973. Escala: 1:50000. Available in: <http://ibge.gov.br>. Access in: September, 30, 2019.

IWAHASHI, J.; PIKE, R. J. Automated classifications of topography from DEMs by an unsupervised nested-means algorithm and a three-part geometric signature. Geomorphology, 86(3-4):409-440, 2007.

JAČKA, L. et al. Assessment of evaluation methods using infiltration data measured in heterogeneous mountain soils. Geoderma, 276:74-83, 2016. 
JAČKA, L. et al. The layering of a mountain podzol can strongly affect the distribution of infiltrated water in the soil profile. Journal of Hydrology and Hydromechanics, 66(3):348-356, 2018.

JARVIS, N. et al. Influence of soil, land use and climatic factors on the hydraulic conductivity of soil. Hydrology and Earth System Sciences Discussions, 17:5185-5195, 2013.

JASIEWICZ, J.; STEPINSKI, T. Geomorphons: A pattern recognition approach to classification and mapping of landforms. Geomorphology, 182(1):147-156, 2013.

JORDA, H. et al. Using boosted regression trees to explore key factors controlling saturated and near-saturated hydraulic conductivity. European Journal of Soil Science, 66(4):744756, 2015.

KAY, B. D. Soil structure and organic carbon: A review. In: LAL, R. et al. Soil Processes and the Carbon Cycle. Boca Raton: CRC Press, 1998. p.169-197.

KURMIANTO, S. et al. The influence of land-cover changes on the variability of saturated hydraulic conductivity in tropical peatlands. Mitigation and Adaptation Strategies for Global Change, 24(4):535-555, 2019.

LAWRENCE, R. et al. Classification of remotely sensed imagery using stochastic gradient boosting as a refinement of classification tree analysis. Remote Sensing of Environment, 90(3):331-336, 2004.

LIAO, W. H. Region description using extended local ternary patterns. 20th International Conference on Pattern Recognition, 1-4, 2010.

LIAW, A.; WIENER, M. Classification and regression by Random Forests. R News, 2/3:18-22, 2002.

MARÍN-CASTRO, B. E. et al. Spatial distribution of hydraulic conductivity in soils of secondary tropical montane cloud forests and shade coffee agroecosystems. Geoderma, 283:57-67, 2016.

MELLO, C. R. et al. Sea surface temperature (SST) and rainfall erosivity in the Upper Grande River Basin, Southeast Brazil. Ciência e Agrotecnologia, 36(1):53-59, 2012.

MELLO, C. R. et al. Water balance in a neotropical forest catchment of southeastern Brazil. Catena, 173:9-21, 2019.

MENEZES, M. D. et al. Dinâmica hidrológica de duas nascentes, associada ao uso do solo, características pedológicas e atributos físico-hídricos na sub-bacia hidrográfica do Ribeirão Lavrinha - Serra da Mantiqueira (MG). Scientia Forestalis, 37(82):175-184, 2009.
MENEZES, M. D. et al. Spatial prediction of soil properties in two contrasting physiographic regions in Brazil. Scientia Agricola, 73(3):274-285, 2016.

MENEZES, M. D. et al. Knowledge-based digital soil mapping for predicting soil properties in two representative watersheds. Scientia Agricola, 75(2):144-153, 2018.

MOUSTAFA, M. M. A geostatistical approach to optimize the determination of saturated hydraulic conductivity for largescale subsurface drainage design in Egypt. Agricultural Water Management, 42(3):291-312, 2000.

NETELER, M., MITASOVA, H. Open source GIS: A grass gis approach. 3.ed. Springer, New York, 2008. 406p.

OCAK, I.; SEKER, S. E. Calculation of surface settlements caused by EPBM tunneling using artificial neural network, SVM, and Gaussian processes. Environmental Earth Sciences, 70(3):1263-1276, 2013.

OLIVEIRA, V. A. et al. Modeling the effects of climate change on hydrology and sediment load in a headwater basin in the Brazilian Cerrado biome. Ecological Engineering, 133:20-31, 2019.

OWUOR, S. O. et al. Conversion of natural forest results in a significant degradation of soil hydraulic properties in the highlands of Kenya. Soil and Tillage Research, 176:3644, 2018.

PACHEPSKY, Y. A. et al. Promises of hydropedology. CAB Reviews: Perspectives in Agriculture, Veterinary Science. Nutrition and Natural Resources, 3(040):119, 2008.

PAHLAVAN-RAD, M. R.; AKBARIMOGHADDAM, A. Spatial variability of soil texture fractions and $\mathrm{pH}$ in a flood plain (case study from eastern Iran). Catena, 160:275-281, 2018.

PAPANICOLAOU, A. N. et al. Spatial variability of saturated hydraulic conductivity at the hillslope scale: Understanding the role of land management and erosional effect. Geoderma, 243-244:58-68, 2015.

PINTO, L. C.; AVILA, L. F.; MELLO, C. R. Water quality index in two land use situations in the Mantiqueira Range. Ciência e Agrotecnologia, 37(4):338-342, 2013.

PINTO, L. C. et al. Role of inceptisols in the hydrology of mountainous catchments in Southeastern Brazil. Journal of Hydrologic Engineering, 21(2):05015017, 2015.

PINTO, L. C. et al. Spatial prediction of soil-water transmissivity based on fuzzy logic in a Brazilian headwater watershed. Catena, 143:26-34, 2016 
PINTO, L. C. et al. Land-use effect on hydropedology in a mountainous region of Southeastern Brazil. Ciência e Agroteconologia, 41(4):413-427, 2017.

PINTO, L. C. et al. A hydropedological approach to a mountainous clayey humic dystrudept in the mantiqueira range, southeastern Brazil. Scientia Agricola, 75(1):60-69, 2018.

PRICE, K.; JACKSON, C. R.; PARKER, A. J. Variation of surficial soil hydraulic properties across land uses in the southern Blue Ridge Mountains, North Carolina, USA. Journal of Hydrology, 383(3-4):256-268, 2010.

REATTO, A. et al. Hydraulic properties of the diagnostic horizon of latosols of a regional toposequence across the Brazilian Central Plateau. Geoderma, 139(1-2):51-59, 2007.

RESENDE, M. et al. Pedologia: Base para distinção de ambientes. 6. ed. Lavras: Editora UFLA, 2014, 378p.

RIENZNER, M.; GANDOLFI, C. Investigation of spatial and temporal variability of saturated soil hydraulic conductivity at the field-scale. Soil and Tillage Research, 135:28-40, 2014.

RONAYNE, M. J.; HOUGHTON, T. B.; STEDNICK, J. D. Field characterization of hydraulic conductivity in a heterogeneous alpine glacial till. Journal of Hydrology, 458-459:103-109, 2012.

SALEMI, L. F. et al. Land-use change in the Atlantic rainforest region: Consequences for the hydrology of small catchments. Journal of Hydrology, 499:100-109, 2013.

SILVA, W. G. S. et al. Relief influence on the spatial distribution of the Atlantic Forest cover at the Ibiúna Plateau, SP. Brazilian Journal of Biology, 67(3):631-640, 2007.

SILVA, S. H. G. et al. Multiple linear regression and random forest to predict and map soil properties using data from portable X-ray fluorescence spectrometer (pXRF). Ciência e Agrotecnologia, 41(6):648-664, 2017.

SIX, J. et al. Soil structure and organic matter. I. Distribution of aggregate-size classes and aggregate-associated carbon. Soil Science Society of America Journal, 64(2):681-689, 2000.

SKORUPA, A. L. A. et al. Xanthic- and Rhodic-Acrudoxes under cerrado vegetation: Differential internal drainage and covarying micromorphological properties. Ciência e Agrotecnologia, 40(4):443-453, 2016.

SOBIERAJ, J. et al. Spatial variability of soil hydraulic conductivity along a tropical rainforest catena. Geoderma, 108(1-2):7990, 2002.

STROBL, C. et al. Bias in random forest variable importance measures: Illustrations, sources and a solution. BMC Bioinformatics, 8(25):1-21, 2007.
TALLAKSEN, L. M. A review of baseflow recession analysis. Journal of Hydrology, 165(1-4):349-370, 1995.

TISDALL, J. M.; OADES, J. M. Organic matter and water-stable aggregates in soils. Journal of Soil Science, 33(2):141-163, 1982.

TISDALL, J. M. Formation of soil aggregates and accumulation of soil organic matter. In: CARTER, M. R.; STEWART, B. A. Structure and Organic Matter Storage in Agricultural Soils. Boca Raton: CRC Press, 1996. p.57-96.

VAPNIK, V. N. Estimation of dependences based on empirical data, Addendum 1, New York: SpringerVerlag, 1982. 413p.

VIOLA, M. R. et al. Impacts of Land-use changes on the hydrology of the Grande River Basin Headwaters, Southeastern Brazil. Water Resource Management, 28(13):4537-4550, 2014.

VIOLA, M. R. et al. Assessing climate change impacts on Upper Grande River Basin hydrology, Southeast Brazil. International Journal of Climatology, 35(6):1054-1068, 2015.

WANG, S. et al. Mapping total soil nitrogen from a site in northeastern China. Catena, 166:134-146, $2018 \mathrm{a}$.

WANG, W. et al. Spatial variation of saturated hydraulic conductivity of a loess slope in the South Jingyang Plateau, China. Engineering Geology, 236:70-78, 2018b.

WIESMEIER, M. et al. Digital mapping of soil organic matter stocks using Random Forest modeling in a semi-arid steppe ecosystem. Plant and Soil, 340(1-2):7-24, 2011.

YANG, R. M. et al. Comparison of boosted regression tree and random forest models for mapping topsoil organic carbon concentration in an alpine ecosystem. Ecological Indicators, 60:870-878, 2016.

ZEVERBERGEN, L. W.; THORNE, C. R. Quantitative analysis of land surface topography. Earth Surface Processes and Landforms, 12:47-56, 1987.

ZIMMERMANN, B.; ELSENBEER, H. Spatial and temporal variability of soil saturated hydraulic conductivity in gradients of disturbance. Journal of Hydrology, 361(1-2):78-95, 2008.

ZIMMERMANN, B.; ELSENBEER, H.; DE MORAES, J .M. The influence of land-use changes on soil hydraulic properties: Implications for runoff generation. Forest Ecology and Management, 222(1-3):29-38, 2006.

ZIMMERMANN, A. et al. Uncovering patterns of near-surface saturated hydraulic conductivity in an overland flowcontrolled landscape. Geoderma, 195-196:1-11, 2013.

ZOMLOT, Z. et al. Spatial distribution of groundwater recharge and base flow: Assessment of controlling factors. Journal of Hydrology: Regional Studies, 4(Parte B):349-368, 2015. 